\begin{tabular}{|c|l|}
\hline Title & $\begin{array}{l}\text { Peristedium indicum Brauer 1906, ajunior synonym of Paraheminodus murrayi (Günther 1880) (Teleostei: } \\
\text { Peristediidae) }\end{array}$ \\
\hline Author(s) & Kawai, Toshio \\
\hline Citation & $\begin{array}{l}\text { Ichthyological Research, 58(1), 67-71 } \\
\text { https://doi.org/10.1007/s10228-010-0183-1 }\end{array}$ \\
\hline Issue Date & 2011-01 \\
\hline Doc URL & http://hdl.handle.net/2115/44927 \\
\hline Rights & The final publication is available at www.springerlink.com \\
\hline Type & article (author version) \\
\hline File Information & IR581_67-71.pdf \\
\hline
\end{tabular}

Instructions for use 
Peristedium indicum Brauer 1906, a junior synonym of Paraheminodus murrayi (Günther 1880) (Teleostei: Peristediidae)

\section{Toshio Kawai}

T. Kawai $(\bowtie)$

Fisheries Science Center, The Hokkaido University Museum, 3-1-1 Minato-cho, Hakodate, Hokkaido 041-8611, Japan

e-mail: +81-138-40-5553

Address: Fisheries Science Center, The Hokkaido University Museum, 3-1-1 Minato-cho,

Hakodate, Hokkaido 041-8611, Japan; Tel/Fax: +81-138-40-5553; e-mail:

kawai@museum.hokudai.ac.jp

Suggested running head: Synonymy of Paraheminodus

Type of paper: Short Report

Number of text pages: 9

Number of figures: 1

Number of tables: 1 
Abstract Peristedium indicum Brauer 1906 (family Peristediidae) has not been reported since its original description. Reexamination of syntypes of $P$. indicum revealed that $P$. indicum is included in the genus Paraheminodus Kamohara 1957 in having upper jaw teeth, smooth lateral margin, posterior parts of lower lateral rows of bony plates separated from each other, and all lower jaw barbels unbranched except for posteriormost barbels. Based on a comparison of syntypes of $P$. indicum with all types and other materials of all congeners of Paraheminodus, it is concluded that $P$. indicum is a junior synonym of Paraheminodus murrayi (Günther 1880).

Keywords Western Indian Ocean · Armored searobin · Synonymy · Redescription · Syntype 


\section{Introduction}

Peristedium indicum Brauer 1906 (family Peristediidae) was described on the basis of five syntypes from off Somali Democratic Republic, western Indian Ocean. However, he did not compare it with any peristediids, except for Peristethus serrulatum Alcock 1898 (now recognized as Scalicus serrulatus; see Kawai 2008). The original description of the species was brief and lacked illustrations and details for species recognition. Peristedium indicum has not been reported since its original description. Reexamination of the two extant syntypes of $P$. indicum (unfortunately the other three syntypes are lost) reveals that $P$. indicum belongs in the genus Paraheminodus Kamohara 1957a. Detailed comparison of both syntypes of P. indicum with all types and non-type specimens of all congeners of Paraheminodus confirms that $P$. indicum is a junior synonym of Paraheminodus murrayi (Günther 1880).

\section{Materials and methods}

Counts and proportional measurements follow Kawai et al. (2004). Standard and head lengths are abbreviated as SL and HL, respectively. Measurements were made with calipers.

Terminology and counts for bony plates and barbels follow Yatou and Okamura (1985), counting all bony plates in each row. Gill rakers, including all rudiments, were counted on the outside of the first arch on the right side. Institutional codes are as follows: Natural History Museum, London, UK (BMNH); Laboratory of Marine Biology, Faculty of Science, Kochi University, Kochi, Japan (BSKU); The Hokkaido University Museum, Hakodate, Japan (HUMZ), Muséum National d'Histoire Naturelle, Paris, France (MNHN), Division of Fisheries Science, Faculty of Agriculture, University of Miyazaki, Miyazaki, Japan (MUFS), National Museum of Nature and Science, Tokyo, Japan (NSMT), Seikai National Fisheries Research Institute, Nagasaki, Japan 
(SNFR), and Museum für Naturkunde, Universitat Humboldt, Berlin, Germany (ZMB).

Material examined. ZMB 17691 (2 specimens), syntypes of Peristedium indicum, 132, 174 mm SL, off Somali Democratic Republic, 0²7'04"S, 4247'03"E, 638 m, 25 March 1899.

\section{Results}

Description of syntypes of Peristedium indicum (Fig. 1a, b). Counts and proportional measurements are provided in Table 1. Body fusiform, covered with bony plates; head large, depressed, and expanded around edges; snout broad; flat and elongated rostral projection on each side (first infraorbital bone); anterior part of rostral projection little wider than its base; interorbital concave; suborbital ridge rudimentary; nasal spines two in $147 \mathrm{~mm}$ SL specimen, both rudimentary in 174 mm SL specimen; mesethmoid spine situated at middle of mesethmoid; preocular spine rudimentary; supraocular spine large and stout on dorsoposterior region of orbit; parietal spine very large and stout; posttemporal spine stout with ridge; supraoccipital exposed on dorsal surface of neurocranium; mouth large and inferior; longitudinal ridge running from base of rostral projection to preopercle; preopercle with single long spine (with additional one rudimentary spine in $174 \mathrm{~mm}$ SL specimen on right side); two opercular spines, upper smaller and lower larger with ridge; gill rakers on first arch sticklike with minute spines on inner side; villiform teeth band on upper jaw; lower jaw, vomer, and palatine toothless; four barbels on lip, anterior three unbranched and posteriormost branched; three barbels on chin unbranched; gill membrane narrowly united to isthmus; bony plates on body arranged in four rows, each plate with one posteriorly directed spine; spines present on dorsal and ventral rows on caudal peduncle, and two wide plates before anus with weak spines; anteriormost bony plates in dorsal row and before anus large; anterior five plates in upper lateral row small; lower lateral row ending at caudal peduncle; dorsal fin originating between first and second bony plates in dorsal row; anal 
fin originating just posterior to first bony plate in ventral row; pectoral fin with two detached and thickened rays; pelvic fin reaching to anus; caudal fin subtruncate.

\section{Discussion}

Kamohara (1957a) established the Indo-West Pacific genus Paraheminodus with Satyrichthys laticephalus Kamohara 1952 as the type species, and characterized it in having a narrow band of teeth on the upper jaw and well developed barbels on lower jaw. Later, some authors synonymized Paraheminodus under Satyrichthys Kaup 1873 without any comments (e.g., Ochiai and Yatou 1984; Yamada 2002), whereas other authors recognized Paraheminodus as a valid taxon (e.g., Miller 1974; del Cerro and Lloris 1997; Richards 1999). Recently, Kawai (2008) reconstructed the phylogenetic relationships among Peristediidae using anatomical data, and provided a diagnosis of the genus Paraheminodus. Both syntypes of Peristedium indicum have the characters of Paraheminodus, i.e., upper jaw teeth present, lateral margin of head smooth, posterior parts of lower lateral rows of bony plates separated from each other, and all but the posteriormost barbels on lower jaw unbranched. The genus Paraheminodus consists of four valid species: Paraheminodus kamoharai Kawai, Imamura, and Nakaya 2004 distributed in Philippines, P. laticephalus in southern Japan, Paraheminodus longirostralis Kawai, Nakaya, and Séret 2008 in New Caledonia, and P. murrayi in Horn of Africa, Maldives, Indonesia, New Caledonia, and southern Japan (Kawai et al. 2008). Four lip barbels and relatively short rostral projection (25.2-32.1\% HL) of the syntypes distinguish them from P. kamoharai, P. laticephalus, and P. longirostralis that have five lip barbels, and from P. kamoharai and P. longirostralis with long rostral projections (42.4-47.0\% HL in the former species and 53.0-59.3\% HL in the latter) and from $P$. laticephalus (22.0\% HL) with very short rostral projections. In addition, the syntypes differ from P. kamoharai and P. longirostralis by lacking forward-directed spines on the 
posterior bony plates of the upper lateral row (vs. having). The characters of the syntypes of $P$. indicum are very close to the other characters of holotype and non-type specimens of $P$. murrayi (Fig. 1). The largest syntype of $P$. indicum has 19 dorsal fin soft rays, a short lower jaw (15.9\% SL), and a short pectoral fin (18.9\% SL), and small specimen having a deep body (22.1\% SL), a high head (20.9\% SL), and a long snout (23.4\% SL), thus are slightly different from the holotype and non-type specimens of P. murrayi that have 20-22, 16.5-19.2\% SL, 19.1-24.9\% SL, 9.4-20.0\% SL, and 10.4-19.4\% SL, respectively (Table 1). Ontogenetic differences in such features in other peristediids have been reported (e.g., Miller 1974; Kawai and Nakaya 2007; Kawai and Takata 2009). Because no significant differences were found in other meristic counts and measurements of all material examined, such differences are considered as an example of intraspecific variation (Table 1). Therefore, it is concluded that $P$. indicum is a junior synonym of P. murrayi. Paraheminodus murrayi has also been known as a senior synonym of Paraheminodus kochiensis Kamohara 1957b (see Kawai et al. 2004).

Comparative materials. Paraheminodus kamoharai: BSKU 15242 (1 specimen), paratype of $P$. kamoharai, 107 mm SL; BSKU 15243, holotype of P. kamoharai, 107 mm SL; BSKU 15244 (1), paratype of P. kamoharai, $115 \mathrm{~mm}$ SL, Sulu Sea, Philippines, $8^{\circ} 11.8^{\prime} \mathrm{N}, 117^{\circ} 58.0^{\prime} \mathrm{E}, 285 \mathrm{~m}, 26$ May 1972. Paraheminodus laticephalus: BSKU 1612, holotype of Satyrichthys laticephalus, 112 mm SL, Mimase Fish Market, Kochi, Japan, 24 January 1952. Paraheminodus longirostralis: HUMZ 185306, holotype of $P$. longirostralis, 135 mm SL, HUMZ 185307 (1), paratype of $P$. longirostralis,136 mm SL, HUMZ 185310 (1), paratype of P. longirostralis, 68.0 mm SL, MNHN 2009-0001 (formerly HUMZ 185308) (1), paratype of P. longirostralis, 125 mm SL, NSMT-P 79585 (1), paratype of P. longirostralis, $125 \mathrm{~mm}$ SL, 21ํㄷ.91'S, $167^{\circ} 12.63^{\prime} \mathrm{E}, 412-467$ m depth, 30 January 2002. Paraheminodus murrayi: BMNH 1879.5.14.265, holotype of Peristethus murrayi, 154 mm SL, Banda Sea, Indonesia; BMNH 1997.9.17.24 (1), 97.3 mm SL, South Maldives, 1977; BSKU 1566 (1), paratype of Paraheminodus kochiensis, 110 mm SL, 
Mimase Fish Market, Kochi, 20 January 1952; BSKU 1610 (1), 117 mm SL, BSKU 1611 (1), paratype of P. kochiensis, 125 mm SL, Mimase Fish Market, Kochi, 24 January 1952; BSKU 4598 (1), paratype of P. kochiensis, 101 mm SL, BSKU 4599 (1), 139 mm SL, Mimase Fish Market, Kochi, 30 April 1955; BSKU 7265, holotype of P. kochiensis, 138 mm SL, Mimase Fish Market, Kochi, 13 May 1957; BSKU 7398 (1), paratype of P. kochiensis, 75.3 mm SL, BSKU 7399 (1), 83.9 mm SL, Mimase Fish Market, Kochi, 16 January 1951; BSKU 12986 (1), 155 mm SL, data unknown; BSKU 40008 (1), 90.1 mm SL, Mimase Fish Market, Kochi, 16 April 1984; HUMZ 191362 (1), 142 mm SL, HUMZ 191363 (1), 133 mm SL, off Sumatra, Indonesia, $5^{\circ} 46.24^{\prime} \mathrm{S}, 102^{\circ} 27.35^{\prime} \mathrm{E}$ to $5^{\circ} 45.50^{\prime} \mathrm{S}, 102^{\circ} 26.15^{\prime} \mathrm{E}, 715-683 \mathrm{~m}$, 26 September 2004; HUMZ 191551 (1), 129 mm SL, HUMZ 191552 (1), 126 mm SL, HUMZ 191553 (1), 130 mm SL, HUMZ 191554 (1), 162 mm SL, HUMZ 191556 (1), 140 mm SL, off Sumatra, Indonesia, $5^{\circ} 46.52^{\prime} \mathrm{S}, 102^{\circ} 41.25^{\prime} \mathrm{E}$ to $5^{\circ} 46.02^{\prime} \mathrm{S}, 102^{\circ} 39.53^{\prime} \mathrm{E}, 546-639 \mathrm{~m}$, 26 September 2004; HUMZ 193650 (1), $139 \mathrm{~mm} \mathrm{SL}$, off Java, Indonesia, $8^{\circ} 19.02^{\prime} \mathrm{S}, 109^{\circ} 45.07^{\prime} \mathrm{E}$ to $8^{\circ} 19.01^{\prime} \mathrm{S}, 109^{\circ} 44.00^{\prime} \mathrm{E}$, 335-400 m, 10 May 2005; HUMZ 193765 (1), 124 mm SL, HUMZ 193766 (1), 92.6 mm SL , HUMZ 193767 (1), 111 mm SL, HUMZ 193768 (1), 103 mm SL, off Java, Indonesia, 8¹2.06’S, $109^{\circ} 11.06^{\prime} \mathrm{E}$ to $8^{\circ} 12.08^{\prime} \mathrm{S}, 1^{\circ} 9^{\circ} 09.08^{\prime} \mathrm{E}, 300-280$ m, 6 May 2005; HUMZ 194094 (1), $128 \mathrm{~mm}$ SL, HUMZ 194096 (1), 137 mm SL, HUMZ 194097 (1), 163 mm SL, HUMZ 194098 (1), 138 mm SL, HUMZ 194099 (1), 147 mm SL, off Sumatra, Indonesia, 545.7'S, $102^{\circ} 32.1^{\prime} \mathrm{E}$ to 546.6'S, 102³3.3'E, 418-405 m, 31 May 2005; MUFS 4578 (1), 118 mm SL, Totoro, Miyazaki, Japan, 24 February 1976; SNFR 11323 (1), 184 mm SL, South China Sea, 14 July 1988.

Acknowledgments I sincerely thank W. J. Richards (National Marine Fisheries Service, Southeast Fisheries Science Center, NOAA) for reviewing manuscript. I am grateful to P. Bartsch and C. Lamour (ZMB) for access to collections, to J. Maclaine (BMNH), H. Endo (BSKU), Y. Iwatsuki (MUFS), and K. Hoshino (SNFR) for specimen loans. I am also grateful to members of JDSTA (Japan Deep Sea Trawlers Association), OFCF (Overseas Fishery 
Cooperation Foundation), and RIMF (Research Institute for Marine Fisheries, Indonesia), and to crews of RV Baruna Jaya IV, for providing an opportunity to sample in Indonesia.

\section{References}

Alcock AW (1898) Natural history notes from H. M. Indian marine survey ship "Investigator," Commander T.H. Heming, R.N., commanding. Series II, no. 25. A note on the deep-sea fishes, with descriptions of some new genera and species, including another probably viviparous ophidioid. Ann Mag Nat Hist (Ser 7) 2:136-156

Brauer A (1906) Die Tiefsee-Fische. I. Systematischer Teil. In: Chun C (ed) Wissenschaftl. Ergebnisse der deutschen Tiefsee-Expedition "Valdivia," 1898-99. Jena. Tiefsee-Fische $15: 1-432$

del Cerro L, Lloris D (1997) Gurnard fishes (Scorpaeniformes, Triglidae) from off New Caledonia, with description of five new species. In: Séret B (ed) Résultats des Campagnes MUSORSTOM, vol 17. Mém Mus Natl Hist Nat Paris 174:91-124

Günther A (1880) Report on the shore fishes procured during the voyage of H. M. S. Challenger in the years 1873-1876. In: Report on the scientific results of the voyage of H. M. S.

Challenger during the years 1873-76. Zool Rep Challenger Shore Fishes 1 (pt 6):1-82, pls $1-32$

Kamohara T (1952) Additions to the offshore bottom-fishes of Prov. Tosa, Japan, with descriptions of two new species. Res Rep Kochi Univ 1:1-3

Kamohara T (1957a) Notes on twenty additions to the marine fish fauna of Prov. Tosa, Japan, including one new genus (family Peristediidae). Res Rep Kochi Univ 6:1-6

Kamohara T (1957b) Some little known fishes from Kochi Prefecture (Prov. Tosa), Japan, including one new species of the family Peristediidae. Jpn J Ichthyol 6:75-81

Kaup JJ (1873) Ueber die Familie Triglidae nebst einigen Worten über die Classification. Arch Naturgesch 39:71-93

Kawai T (2008) Phylogenetic systematics of the family Peristediidae (Teleostei: Actinopterygii). 
Species Divers 13:1-34

Kawai T, Imamura H, Nakaya K (2004) Paraheminodus kochiensis Kamohara, 1957 (Teleostei: Peristediidae), a junior synonym of Paraheminodus murrayi (Günther, 1880), with a comparison of Paraheminodus murrayi and Paraheminodus laticephalus (Kamohara, 1952). Ichthyol Res 51:73-76

Kawai T, Nakaya K (2007) Redescription of a rare armored gurnard, Heminodus philippinus (Actinopterygii: Teleostei: Peristediidae). Species Divers 12:167-173

Kawai T, Nakaya K, Séret B (2008) A new armored searobin Paraheminodus longirostralis (Teleostei: Peristediidae) from New Caledonia. Ichthyol Res 55:374-378

Kawai T, Takata Y (2009) Satyrichthys rugosus, a junior synonym of Satyrichthys clavilapis (Actinopterygii: Teleostei: Peristediidae). Species Divers 14:89-96

Miller GC (1974) Fische des Indian Ozeans. Ergebnisse der ichthyologischen Untersuchungen während der Expedition des Forschungsschiffes “Meteor” in den Indischen Ozean, Oktober 1964 bis Mai 1965. A. Systematischer Teil, XIV, Scorpaeniformes (2) Family Peristediidae. Meteor Forschergeb Reihe D Biol (18):61-72

Ochiai A, Yatou T (1984) Peristediidae. In: Masuda H, Amaoka K, Araga C, Uyeno T, Yoshino T (eds) The fishes of the Japanese Archipelago. Tokai Univ Press, Tokyo, pp 334-336, pls 301-302, 364

Richards WJ (1999) Triglidae. In: Carpenter KE, Niem VN (eds) FAO species identification guide for fishery purposes. The living marine resources of the western central Pacific, vol 4. Bony fishes part 2 (Mugilidae to Carangidae). FAO, Rome, pp 2359-2382

Yamada U (2002) Peristediidae. In: Nakabo T (ed) Fishes of Japan with pictorial keys to the species, English edn. Tokai University Press, Tokyo, pp 610-613, 1523

Yatou T, Okamura O (1985) Satyrichthys isokawae Yatou et Okamura, sp. nov. In: Okamura O (ed) Fishes of the Okinawa Trough and the adjacent waters, vol 2. Jpn Fish Resour Cons Assoc, Tokyo, pp 586-589 
Figure legends

Fig. 1 Paraheminodus murrayi: a syntype of Peristedium indicum, ZMB 17691, 132 mm SL; b syntype of Peristedium indicum, ZMB 17691, 174 mm SL; c holotype of Paraheminodus murrayi, BMNH 1997.9.17.24, 154 mm SL 
Table 1 Comparison of Peristedium indicum and Paraheminodus murrayi

\begin{tabular}{|c|c|c|c|c|}
\hline & \multicolumn{2}{|l|}{$P$. indicum } & \multicolumn{2}{|c|}{ P. murrayi } \\
\hline & Syntypes $(n=2)$ & & Holotype & Others $(n=30)$ \\
\hline & ZMB 27691 & & BMNH 1879.5.14.265 & \\
\hline Standard length (mm) & 132 & 174 & 154 & 75.3-184 \\
\hline Counts & & & & \\
\hline Dorsal fin rays & VII, 19 & VII, 20 & VII, 21 & VII, 20-22 \\
\hline Anal fin rays & 20 & 20 & 21 & $20-21$ \\
\hline $\begin{array}{l}\text { Pectoral fin rays (including two } \\
\text { detached rays) }\end{array}$ & 17 & 17 & 19 & $17-18$ \\
\hline Pelvic fin rays & $\mathrm{I}, 5$ & $\mathrm{I}, 5$ & $\mathrm{I}, 5$ & $\mathrm{I}, 5$ \\
\hline Principal caudal fin rays & Broken & 11 & 11 & $11-13(n=29)$ \\
\hline Bony plates in dorsal row & 28 & 29 & 30 & $28-30$ \\
\hline Bony plates in upper lateral row & 34 & 34 & 35 & $34-36$ \\
\hline Bony plates in lower lateral row & 23 & 24 & 24 & $22-25$ \\
\hline Bony plates in ventral row & 24 & 25 & 26 & $24-28$ \\
\hline Bony plates before anus & 2 & 2 & 2 & $2-4$ \\
\hline $\begin{array}{l}\text { Bony plates in upper lateral row with a } \\
\text { forwardly directed spine }\end{array}$ & Absent & Absent & Absent & Absent \\
\hline Gill rakers & $3+1+14=18$ & No data ${ }^{a}$ & $3+1+13=17$ & $\begin{array}{l}4-5+1+13-15= \\
18-20\end{array}$ \\
\hline Barbels (lip + chin) & $4+3$ & $4+3$ & $4+3$ & $4+3$ \\
\hline Branchiostegal rays & 7 & 7 & 7 & 7 \\
\hline Measurements (\%SL) & & & & \\
\hline Body depth & 22.1 & 19.6 & 20.0 & $9.4-20.0$ \\
\hline Body width & 12.8 & 13.2 & 12.3 & $10.6-16.0$ \\
\hline Head length & 43.1 & 40.7 & 42.8 & $39.2-45.3$ \\
\hline Head depth & 20.9 & 18.0 & 19.4 & $10.4-18.7$ \\
\hline Head width & 33.9 & 29.0 & 31.4 & $26.4-37.3(n=28)$ \\
\hline Snout to dorsal fin & 43.8 & 40.8 & 41.3 & $38.9-43.9$ \\
\hline Snout to anal fin & 54.9 & 52.4 & 56.3 & $49.9-57.4$ \\
\hline Snout to anus & 50.9 & 47.7 & 51.9 & $44.7-50.6$ \\
\hline Snout length & 23.4 & 21.3 & 22.7 & $20.0-23.3$ \\
\hline Rostral projection length & 13.8 & 10.3 & 11.7 & $10.1-15.0(n=19)$ \\
\hline Longest barbel length & 35.7 & 35.1 & 28.4 & $24.6-37.6$ \\
\hline Upper jaw length & 21.8 & 20.0 & 21.7 & $19.4-22.7$ \\
\hline Lower jaw length & 16.6 & 15.9 & 17.2 & $16.5-19.2$ \\
\hline
\end{tabular}




\begin{tabular}{lllll} 
Orbital diameter & 10.1 & 9.3 & 8.9 & $8.5-10.9$ \\
Interorbital width & 7.3 & 7.9 & 7.7 & $6.9-9.8(n=27)$ \\
Pectoral fin length & 23.6 & 18.9 & 23.0 & $19.1-24.9$ \\
Upper detached pectoral fin ray length & No data $^{\mathrm{b}}$ & No data $^{\mathrm{b}}$ & 18.8 & $16.1-21.3$ \\
Lower detached pectoral fin ray length & No data $^{\mathrm{b}}$ & No data $^{\mathrm{b}}$ & 15.4 & $13.9-17.5$ \\
Pelvic fin length & 19.3 & 16.9 & 17.4 & $16.2-21.0$ \\
First dorsal spine length & Broken & Broken & 8.8 & $7.1-10.4(n=28)$ \\
Caudal peduncle length & 8.2 & 9.2 & 8.9 & $7.2-10.1$ \\
Caudal peduncle depth & 2.8 & 2.6 & 2.8 & $2.4-3.2$ \\
\hline
\end{tabular}

${ }^{a}$ Unable to open gill opening because of hard and dried fixation

${ }^{\mathrm{b}}$ Unable to measure because of bent and dried fixation 
a

b

(2)

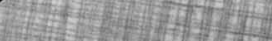

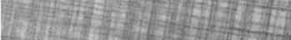

A.
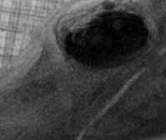
ans:

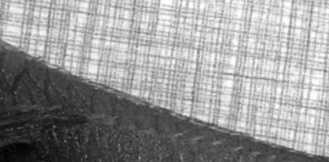

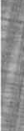

C

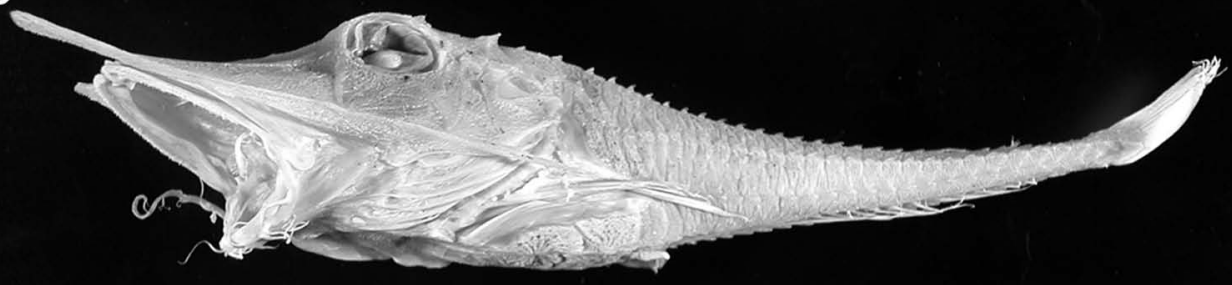

